\title{
Effectiveness of vessel sinking legal action in eradicating illegal fishing in the area of marine and fisheries resources monitoring base of Bitung, North Sulawesi
}

\section{Efektivitas tindakan hukum penenggelaman kapal dalam pemberantasan illegal fishing di wilayah Pangkalan Pengawasan Sumber Daya Kelautan dan Perikanan Bitung, Sulawesi Utara}

\author{
Youdy R. Suawa, ${ }^{1}$ Alfret Luasunaung, ${ }^{2 *}$ Markus T. Lasut, ${ }^{2}$ Denny B.A. Karwur, ${ }^{3}$ \\ and Suria Darwisito ${ }^{3}$ \\ ${ }^{I}$ Program Studi Magister Ilmu perairan, Fakultas Perikanan dan Ilmu Kelautan, Universitas Sam Ratulangi. \\ Jl. Kampus Unsrat Bahu, Manado 95115 \\ ${ }^{2}$ Fakultas Perikanan dan Ilmu Kelautan, Universitas Sam Ratulangi, Manado \\ ${ }^{3}$ Fakultas Hukum, Universitas Sam Ratulangi, Manado \\ *E-mail: alfret_luasunaung@yahoo.com
}

\begin{abstract}
This study aimed to assess the effectiveness of vessel sinking legal action to eradicate illegal fishing practices by the Ministry of Marine and Fisheries Affairs of Indonesia (MMFAI) in the area of Marine and Fisheries Resources MonitoringBase of Bitung (MFRMBB), North Sulawesi. The assessment was carried out by analysing five aspects, 1) regulations; 2) institutional functions, duties, and authority; 3) institutional programs and planning; 4) ideal conditions; and 5) stakeholder perceptions. The research used a method of 'content analysis' and questionnaire survey. The result showed that the implementation to sink foreign and ex-foreign vessels by MMFAI is a legal certainty according to fisheries regulations in Indonesia; it was conducted according to functions, duties, and authorities of the implemented institutions; was conducted well; and has achieved an ideal condition which was indicated by diminishing of illegal fishing practices; it was done according to fisheries regulations and stakeholder perceptions. Finally, it can be concluded that the legal action of vessel-sinking in MFRMBB was effective in eradicating illegal fishing practices.
\end{abstract}

Keywords: illegal fishing; vessel sinking; marine and fisheries resources; Bitung; Indonesia.

Abstrak: Penelitian ini bertujuan untuk menilai efektifitas tindakan penenggelaman kapal untuk memberantas illegal fishing oleh Kementerian Kelautan dan Perikanan (KKP) RI di Pangkalan Pengawasan Sumber Daya Kelautan dan Perikanan Bitung, Sulawesi Utara. Penilaian dilakukan dengan cara menganalisis 5 aspek, yaitu: 1) peraturan dan ketentuan; 2) fungsi, tugas, dan wewenang lembaga pelaksana; 3) program dan rencana lembaga pelaksana; 4) kondisi ideal; dan 5) persepsi stakeholder. Metode penelitian yang digunakan ialah analisis isi (content analysis) dan survei menggunakan angket. Hasil penelitian menunjukan, bahwa implementasi penenggelaman kapal asing dan eks asing yang dilakukan oleh KKP merupakan suatu kepastian hukum sesuai ketentuan dan peraturan dan perundang-undangan di bidang perikanan yang berlaku; telah dilaksanakan sesuai fungsi, tugas, dan kewenangan KKP RI; telah terlaksana dengan baik; dan telah mencapai kondisi ideal di mana ditandai dengan berkurangnya pelaku tindak pidana perikanan; serta tindakan tersebut sudah sesuai dengan ketentuan dan peraturan yang berlaku di bidang perikanan, menurut persepsi stakeholder. Dengan demikian, dapat disimpulkan, bahwa tindakan hukum penenggelaman kapal yang dilakukan di Pangkalan Pengawas Sumber Daya Kelautan dan Perikanan Bitung adalah efektif dalam memberantas kegiatan illegal fishing.

Kata-kata kunci: illegal fishing; penenggelaman kapal; sumber daya kelautan dan perikanan; Bitung; Indonesia.

\section{PENDAHULUAN}

Mahmudah (2015) mengatakan, maraknya kasus pencurian ikan oleh kapal-kapal asing menggunakan peralatan canggih dan anak buah kapal (ABK) asing mengindikasikan upaya perlindungan terhadap wilayah perairan Indonesia harus lebih ditingkatkan lagi. Lemahnya pengawasan dan penegakan hukum terhadap para pelaku illegal fishing telah menyebabkan para pelakunya tidak pernah jera. Kerugian negara akibat kegiatan ini dikhawatirkan semakin meningkat sejalan dengan semakin banyaknya jumlah kasuskasus pelanggaran di bidang perikanan. Berdasar- 
kan data FAO, kerugian Indonesia per tahun akibat illegal fishing, diperkirakan, sebesar Rp 30 triliun; tetapi jumlah tersebut dinilai masih kecil di mana sebenarnya bisa mencapai Rp 240 triliun (Mahmudah, 2015).

Menurut Nikijuluw (2008), illegal fishing adalah kegiatan pencurian ikan atau penjarahan sumber daya ikan dengan melanggar aturan yang berlaku. Oleh karena itu, Kementerian Kelautan dan Perikanan Republik Indonesia (KKP RI), sebagai leading sektor utama pengambil keputusan dan kebijakan dalam pengelolaan dan pemanfaatan sumber daya kelautan dan perikanan, dengan tegas melakukan upaya pemberantasan illegal fisihing. Salah satu tindakan tegas yang dilakukan oleh KKP $\mathrm{RI}$ adalah dengan melakukan penenggelaman kapal asing dan eks-asing pelaku illegal fishing sebagai langkah nyata dalam implementasi hukum.

Tugas dan fungsi kapal pengawas perikanan, yang dinyatakan dalam Undang-Undang Republik Indonesia (UU RI), nomor 45, tahun 2009, tentang perikanan, Pasal 69, adalah melaksanakan pengawasan dan penegakan hukum di bidang perikanan dalam wilayah pengelolaan perikanan negara Republik Indonesia (ayat 1). Selain itu, dinyatakan juga, bahwa penyidik dan/atau pengawas perikanan dapat melakukan tindakan khusus berupa pembakaran dan/atau penenggelaman kapal perikanan yang berbendera asing berdasarkan bukti permulaan yang cukup (ayat 4). Dalam UU RI tersebut, dinyatakan juga, bahwa melakukan tindak pidana perikanan merupakan aksi negara dalam memberatas kegiatan perikanan illegal, dan disamping itu, juga untuk memberikan efek jera dan menjaga kedaulatan Negara.

Tindakan hukum Penenggelaman kapal terhadap kapal pelaku illegal fishing telah dilakukan. Untuk menilai keefektifan tindakan tersebut, maka dilakukan penelitian, yang bertujuan untuk menilai efektifitas tindakan hukum penenggelaman kapal dalam memberantas illegal fishing oleh KKP RI di wilayah Pangkalan Pengawasan Sumber Daya Kelautan dan Perikanan Bitung (PPSDKP Bitung), Sulawesi Utara. Penilaian dilakukan dengan menganalisis 5 aspek, yaitu: 1) peraturan dan ketentuan; 2) fungsi, tugas, dan wewenang lembaga pelaksana; 3) program dan rencana lembaga pelaksana; 4) kondisi ideal; dan 5) persepsi stakeholder.

\section{MATERIAL DAN METODE}

Penelitian ini dilakukan di wilayah PPSDKP Bitung. Kantor PPSDKP Bitung terletak di
Kelurahan Aertembaga Dua, Kecamatan Aertembaga, Kota Bitung, Provinsi Sulawesi Utara. Penelitian ini dilaksanakan pada bulan Juli 2018 sampai dengan Desember 2018.

Metode penelitian yang digunakan adalah analisis isi (content analysis) (Yuris, 2018) dan survei menggunakan engket. Data dikumpulkan melalui 3 cara (Satori et al., 2009), yaitu 1) dokumentasi (documentation); data yang diperoleh berupa data dari dokumen yang diperoleh dari instansi penengak hukum yang berwenang terkait dalam hal tindakan hukum kapal perikanan yang ditenggelamkan; 2) wawancara (interview); untuk menggumpulkan data primer yang berkaitan dengan pelaksanaan kegiatan penenggelaman kapal perikanan yang melakukan kegiatan illegal fishing; kriteria responden yang akan diwawancarai dalam penelitian ini adalah: kelompok orang yang berwenang secara formal (misalnya: petugas pemerintah atau pegawai pada instansi pemerintahan yang bekerja sesuai tugas pokok yang dikerjakan secara langsung dalam penanganan kegiatan illegal fishing), dan kelompok akademisi, pemilik kapal, dan masyarakat nelayan yang ada di lokasi penelitian; 3) angket (questionnaire); menggunakan pertanyaan atau pernyataan yang diberikan kepada responden, baik secara langsung maupun tidak langsung; dalam penelitan ini, digunaken angket secara langsung.

Menurut Wibisono (2018) dan Zebblon (2015), untuk mengetahui persepsi stakeholder dalam penelitian ini, seseorang yang dipilih sebagai responden adalah orang yang dianggap memiliki informasi yang akurat dan memiliki kewenangan atau informasi yang akurat tentang efektifitas tindakan hukum perikanan penenggelaman kapal. Kelompok dan jumlah responden yang digunakan dalam penelitian ini adalah merupakan para pejabat pemerintah pusat dan daerah, yang ada di lokasi penelitian. Adapun asal instansi dan jumlah responden tersebut, yaitu 1) PPSDKP Bitung (1 orang), Kejaksaan (1 orang), Hakim (1 orang), Dinas Kelautan Perikanan (DKP) Provinsi (1 orang), Penyidik TNI-AL (1 orang), Penyidik Polair (1 orang), dan Imigrasi Kelas II Bitung (1 orang); 2) akademisi (200 orang); 3) pemilik kapal perikanan (200 orang); dan 4) nelayan (200 orang). Jumlah responden keseluruhan sebanyak 607 orang.

\section{HASIL DAN PEMBAHASAN}

\section{Aspek Peraturan dan Ketentuan}

Penenggelaman terhadap kapal pelaku Illegal Fishing yang tidak memiliki dokumen resmi atau melanggar ketentuan hukum RI merupakan 
Suawa et al.: Effectiveness of vessel sinking legal action in eradicating illegal fishing in the area of marine ...

tindakan yang didasarkan pada ketentuan Pasal 69, Ayat 1 dan 4, UU RI, nomor 45, tahun 2009, tentang Perikanan. Kapal pengawas perikanan berfungsi melaksanakan pengawasan dan penegakan hukum di bidang perikanan dalam wilayah pengelolaan perikanan Negara Republik Indonesia, dan penyidik dan/atau pengawas perikanan dapat melakukan tindakan khusus berupa pembakaran dan/atau penenggelaman kapal perikanan berbendera asing berdasarkan bukti permulaan yang cukup. Selanjutnya, tindakan pemusnahan merujuk pada ketentuan Pasal 76 (a) dalam UU RI tersebut, yaitu benda atau alat yang digunakan atau dihasilkan dari pidana perikanan dapat dirampas atau dimusnahkan setelah mendapat persetujuan pengadilan. Peraturan dan ketentuan lain, sebagai dasar dari tindakan penenggelaman kapal, adalah Instruksi Presiden (Inpres), nomor 15, tahun 2011, tentang perlindungan nelayan di mana KKP RI menindak tegas setiap pelaku kejahatan perikanan yang melakukan penangkapan ikan secara illegal, baik tidak melaporkan (illegal, underported, Unreguleted fishing) dan penangkapan ikan yang merusak (destructive fishing) di Wilayah Pengelolaan Perikanan Negara Republik Indonesia (Point 4, huruf F). Dengan demikian, tindakan hukum di atas sesuai dengan ketentuan dan perundang-undangan di bidang perikanan yang berlaku.

\section{Aspek Tugas dan Fungsi KKP RI}

Menurut Peraturan Presiden RI, nomor 63, tahun 2015, tentang Kementerian Kelautan dan Perikanan Republik Indonesia, bahwa KKP RI memiliki tugas dan fungsi, sebagai berikut: a. perumusan, penetapan, dan pelaksanaan kebijakan di bidang kelautan dan perikanan;

b. pengelolaan barang milik/kekayaan negara yang menjadi tanggung jawab KKP;

c. pengawasan atas pelaksanaan tugas di lingkungan KKP;

d. pelaksanaan bimbingan teknis, dan supervisi atas pelaksanaan urusan KKP di daerah; dan

e. pelaksanaan kegiatan teknis yang berskala nasional.

Peraturan Presiden RI, nomor 2, tahun 2015 , tentang rencana pembangunan jangka menengah nasional (RPJMN) Tahun 2015-2019, menjelaskan tentang strategi pembangunan nasional yang terkait dengan tugas dan fungsi KKP, yang juga terdapat dalam agenda prioritas pembangunan nasional (Nawacita) dan dituangkan dalam tugas dan fungsi Direktorat Jenderal PSDKP (berdasarkan PermenKP Nomor 23/PERMEN-KP/2015 tentang Organisasi dan Tata Kerja Kementerian Kelautan dan Perikanan) di mana tugas dan fungsi Direktorat Jenderal PSDKP adalah menyelenggarakan perumusan dan pelaksanaan kebijakan di bidang pengawasan, pengelolaan sumber daya kelautan dan perikanan (Dirjen PSDKP, 2014).

Berdasarkan hal tersebut di atas, maka tindakan hukum penenggelaman kapal terhadap kapal pelaku illegal fishing dilaksanakan sesuai fungsi, tugas, dan kewenangan KKP RI.

\section{Aspek Program dan Rencana}

Menurut Nasirin and Hermawan (2017), kebijakan penenggelaman kapal asing dan eks-asing yang dilakukan oleh KKP RI merupakan wujud dari visi kedaulatan negara di bidang kelautan dan

Tabel 1. Persepsi Stakeholder terhadap tindakan hukum penenggelaman kapal pelaku illegal fishing di wilayah Pangkalan Pengawasan Sumber Daya Kelautan dan Perikanan Bitung, Sulawesi Utara

\begin{tabular}{|c|c|c|c|}
\hline Stakeholder & Jumlah & Setuju & Tidak Setuju \\
\hline $\begin{array}{l}\text { Pemerintah Pusat, Daerah, dan petugas penengak hukum (Penyidik } \\
\text { Perikanan), Kejaksaan, Hakim, Dinas Kelautan dan Perikanan, Penyidik } \\
\text { Tentara Nasional Indonesia, Angkatan Laut, Penyidik Polair Polda, } \\
\text { Imigrasi }\end{array}$ & 7 & $88,72 \%$ & $11,28 \%$ \\
\hline & 200 & $78,18 \%$ & $21,82 \%$ \\
\hline Akademisi & & & \\
\hline Nelayan & 200 & $72,00 \%$ & $28,00 \%$ \\
\hline Pemilik Kapal & 200 & $73,43 \%$ & $26,57 \%$ \\
\hline
\end{tabular}


perikanan. KKP RI telah menetapkan visi kedaulatan, yaitu "membangun kedaulatan yang mampu menopang kemandirian ekonomi dalam pengelolaan sumber daya kelautan dan perikanan". Visi tersebut kemudian dioperasionalisasikan kedalam misi, berupa kebijakan "membangun kedaulatan yang mampu menopang kemandirian ekonomi dalam pengelolaan sumber daya kelautan dan perikanan". Untuk mewujudkan misi tersebut, maka disusunlah beberapa strategi, yang salah satunya adalah memberantas illegal, unreported, and unregulated fishing (IUUF).

Salah satu tindakan operasional pemberantasan IUUF, yang dilakukan oleh KKP RI, adalah penenggelaman kapal (Rencana Strategis Kementerian Kelautan dan Perikanan 2015-2019). Pelaksanaan kebijakan penenggelaman kapal asing dan eks-asing oleh KKP ditandai dengan beberapa hal, yaitu:

a. Dukungan kepastian peraturan perundangundangan, keputusan presiden, dan ketetapan lembaga penegak hukum, yang melegitimasi pelaksanaan kebijakan penenggelaman kapal di mana mengacu pada Pasal 69, Ayat (4) UU RI, nomor 45 , tahun 2009 , tentang perikanan, yaitu penyidik dan/atau pengawas perikanan dapat melakukan tindakan khusus berupa pembakaran dan/atau penenggelaman kapal perikanan yang berbendera asing berdasarkan bukti yang cukup, dan berdasarkan standar operasional prosedur soal eksekusi penenggelaman kapal asing (berdasarkan PermenKP RI, nomor 37/Permen$\mathrm{KP} / 2017$ tentang standar prosedur penegakkan hukum satuan tugas pemberantasan penangkapan ikan secara illegal (illegal Fishing), dan Peraturan Dirjen PSDKP, nomor 11, tahun 2014, tentang petunjuk teknis pelaksanaan tindakan khusus terhadap kapal perikanan berbendera asing.

b. Melaksanakan pola instruksional dan koordinasi penenggelaman kapal asing dan eks asing pelaku illegal fishing di mana penenggelaman kapal dijalankan dengan pola instruksional dari Presiden kepada KKP RI dan lembaga peradilan kepada KKP dengan berkoordinasi dengan instansi terkait lainnya, seperti Kementerian Politik, Hukum dan Keamanan, Kementerian Luar Negeri, Mahkamah Agung, Jaksa Agung, Kementerian Luar Negeri, TNI Angkatan Laut, dan sebagainya.

c. Implementasi kebijakan penenggelaman kapal asing dan eks-asing dilaksanakan dengan komitmen tinggi dari top management sehingga pelaksanaan kebijakan tersebut memiliki karakter progresif, konsisten, tegas, dan berkesinambungan untuk membuahkan hasil yang jelas. Walaupun kebijakan penenggelaman kapal tersebut mendapatkan kecaman dari dalam maupun luar negeri, namun tindakan penenggelaman kapal tetap dilaksanakan.

d. Dukungan pendanaan untuk pemberantasan illegal fishing untuk pelaksanaan penenggelaman kapal, yang dipimpin langsung oleh Menteri Kelautan dan Perikanan RI sebagai Komandan Satgas.

e. Dukungan instrumen birokrasi Satuan Tugas 115 atau dikenal dengan Satgas 115 yang handal untuk mengeksekusi penenggelaman kapal. Satuan Tugas 115 ditugaskan untuk melakukan pemberantasan penangkapan ikan secara iIlegal melalui PP RI, nomor 115, tahun 2015, tentang Satuan Tugas Pemberantasan Penangkapan Ikan Secara Ilegal.

\section{Aspek Kondisi Ideal Peraturan}

Mahkamah Agung RI mendukung harapan pemerintah untuk memberikan hukuman, yang dapat menimbulkan efek jera bagi terdakwa, perusahaan, pemilik/operator kapal, yang melakukan tindak pidana perikanan di wilayah kedaulatan hukum laut Indonesia, dengan didukung oleh Surat Edaran Mahkamah Agung, nomor 1, tahun 2015, tentang barang bukti kapal perkara pidana perikanan. Sejalan dengan itu, dengan menagacu pada Pasal 69, Ayat 4, UU RI, nomor 45, tahun 2009, tentang Perikanan, maka barang bukti kapal yang digunakan untuk melakukan kejahatan pencurian ikan di laut dapat ditenggelamkan atau dimusnahkan.

Dampaknya, kegiatan illegal fishing yang terjadi di wilayah perairan di Laut Sulawesi, Laut Maluku dan Laut Halmahera, oleh kapal ikan asing ataupun kapal ikan Indonesia, dapat ditekan atau berkurang. Hal ini disebabkan oleh adanya hal-hal sebagai berikut:

- Moratorium Kapal Ikan dan ABK Asing. Dengan adanya kebijakan KKP RI tentang moratorium kapal ikan dan ABK asing, maka kegiatan illegal fishing berkurang. Hal itu terjadi, karena semua kapal ikan asing dan ABK asing tidak dapat lagi beroperasi ataupun melakukan kegiatan perikanan tangkap di perairan Indonesia. Kebijakan KKP RI tersebut adalah PermenKP RI, nomor 56/PERMEN. $\mathrm{KP} / 2014$, tentang Penghentian Sementara (moratorium) Perizinan Usaha Perikanan Tangkap di Wilayah Pengelolaan Perikanan Negara Republik Indonesia, dan PermenKP RI, nomor 57/PERMEN.KP/2014, tentang perubahan kedua atas PermenKP RI, nomor Per.30/ 
Suawa et al.: Effectiveness of vessel sinking legal action in eradicating illegal fishing in the area of marine ...

MEN/2012, tentang Usaha Perikanan Tangkap di Wilayah Pengelolaan Perikanan Negara Republik Indonesia, khususnya dalam hal penghentian kegiatan alih muatan (transhipment) di laut.

- Kebijakan terkait Penenggelaman Kapal Pelaku Illegal Fishing. Kebijakan KKP RI terhadap para pelaku tindak pidana perikanan dengan cara melakukan penenggelaman kapal asing yang terbukti melakukan kegiatan illegal fishing merupakan suatu kebijakan yang tepat dalam memeranggi illegal fishing dan juga sebagai tindakan efek jera kepada para pelakunya.

\section{Aspek Persepsi Stakeholder terhadap Tindakan Penenggelaman Kapal}

Dalam menanggulangi kegiatan illegal fishing diperlukan peran berbagai pihak sebagai pemangku kepentingan (stakeholder), baik dari pemerintah pusat, pemerintah daerah, aparat penegakan hukum, kelompok masyarakat pengawas (POKMASWAS), maupun dari pelaku usaha perikanan sehingga kegiatan illegal fishing tersebut dapat dihentikan dan tujuan utama pengelolaan sumber daya perikanan dengan baik dapat tercapai. Tabel 1 menampilkan hasil survei terhadap 4 kelompok stakeholder.

Hasil tersebut (Tabel 1) menunjukkan, bahwa semua stakeholder di wilayah Pangkalan Pengawasan Sumber Daya Kelautan dan Perikanan Bitung "setuju" dengan tindakan hukum penenggelaman terhadap kapal pelaku illegal fishing. Walaupun demikian, persentase "setuju" bervariasi $72,00-88,72 \%$.

\section{KESIMPULAN}

Dari penelitian ini dapat disimpulkan, bahwa tindakan hukum penenggelaman kapal yang dilakukan oleh KKP RI di wilayah Pangkalan Pengawas Sumber Daya Kelautan dan Perikanan Bitung adalah efektif dalam memberantas kegiatan illegal fishing.

\section{REFERENSI}

DIRJEN PSDKP (2014) Peraturan Dirjen PSDKP No.11 2014. Tentang Petunjuk Teknis Pelaksanaan Tindakan khusus terhadap kapal Perikanan Berbendera Asing. Jakarta.

MAHMUDAH, N. (2015) Illegal Fishing Pertanggungjawaban Pidana Korporasi. Jakarta: Sinar Grafika.
NASIRIN and HERMAWAN (2017) Kontroversi Implementasi Kebijakan Penenggelaman Kapal Dalam Rangka Pemberantasan Illegal Fishing di Indonesia.

NIKIJULUW, V.P.H. (2008) Dimensi Sosial Ekonomi Perikanan Illegal Blue Water Crime. Jakarta: PT. Pustaka Cidesindo.

SATORI, D., KOMARIAH, A. AND RIDWAN (2009) Metodologi Penelitian Kualitatif. Bandung: CV. Alfa Beta.

WIBISONO (2018) Pengertian Stakeholder, Klasifikasi Jenis, Peran, Fungsi dan Hubungan Perusahaan Dengan Stakeholder Lengkap. http://www.pelajaran.co.id/2018/28/pengertian-klasifikasi-jenisperan-fungsi-dan-hubungan-perusa-haandengan-stakeholder.html. Diakses pada 1 Juni 2018.

YURIS, A. (2018) Pengertian content analysis, Berkenalan dengan Analisis isi (content analysis)

https://andreyuris.wordpress.com/2009/09/02/a nalisis-isi-content-analysis/. Diakses pada 2 Juni 2018.

ZEBBLON, P.C. (2015) Persepsi Masyarakat dan Strategi Kebijakan dalam Penerapan EcoFsihing Port di Pelabuhan Perikanan Samudera Bitung. Manado: Universitas Sam Ratulangi.

\section{Referesi Tambahan:}

Intruksi Presiden Republik Indonesia No. 15 Tahun 2011 tentang Perlindungan Nelayan, Jakarta

Kementerian Kelautan dan Perikanan, 2012. Keputusan Menteri Republik Indonesia No. 50 Tahun 2012 tentang Rencana Aksi Nasional Pencegahan dan Penanggulangan Illegal Unreported, and Unregulated Fishing Tahun 2012-2016, Jakarta.

Peraturan Presiden Republik Indonesia No. 2 Tahun 2005. Rencana Pembangunan Jangka Menengah Nasional (RPJMN) Tahun 2015-2019 Presiden Republik Indonesia.

Piagam Kesepakatan Bersama antara Kementerian Kelautan dan Perikanan RI, Tentara Nasional Indonesia AL, dan Kepolisian RI, 2015. No.121/DJPSDKP/VIII/2012,

No.B/32/VIII/2012, No. PKB/14/VIII/2012.

Rencana Strategi Direktorat Perikanan Tangkap Kementerian Kelautan dan Perikanan RI Tahun 2015-2019. Jakarta.

Tentang Standar Operasional dan Prosedur Penanganan Tindak Pidana Perikanan pada Tingkat Penyidikan, Jakarta 
Journal of Aquatic Science \& Management, Vol. 7, No. 1 (April 2019)

Undang-Undang No. 45 tahun 2009. Perubahan Undang-Undang No.31 tahun 2004 tentang Perikanan. Presiden Republik Indonesia.
Undang-Undang Nomor 31 Tahun 2004 tentang Perikanan. Presiden Republik Indonesia.

Received: 15 February 2019 Accepted: 30 April 2019 